\title{
Synergy of 1,25-dihydroxyvitamin D3 and carboplatin in growth suppression of $\mathrm{SKOV}-3$ cells
}

\author{
ZENGLI ZHANG $^{1 *}$, HEMEI ZHANG ${ }^{1 *}$, ZHIYONG HU $^{2 *}$, PING WANG $^{1}$, JIANMEI WAN $^{1}$ and BINGYAN LI ${ }^{1}$ \\ ${ }^{1}$ Department of Toxicology, School of Public Health, Soochow University, Suzhou, Jiangsu 215123; \\ ${ }^{2}$ Li Shui Center for Disease Control and Prevention, Lishui, Zhejiang 323000, P.R. China
}

Received December 12, 2013; Accepted May 29, 2014

DOI: 10.3892/ol.2014.2307

\begin{abstract}
Dihydroxyvitamin D3 $\left[1,25(\mathrm{OH})_{2} \mathrm{D}_{3}\right]$ has been demonstrated to inhibit the growth of cancer cells. However, carboplatin is the most widely used chemotherapeutic agent to treat cancer. We hypothesized that vitamin D may enhance the antiproliferative effects of carboplatin, and tested this hypothesis in ovarian cancer SKOV-3 cells treated with carboplatin and $1,25(\mathrm{OH})_{2} \mathrm{D}_{3}$. Cell viability was determined by Cell Counting Kit-8, while cell cycle distribution, apoptosis, reactive oxygen species (ROS) and mitochondrial membrane potential (MMP) were analyzed by flow cytometry. In these experiments, $1,25(\mathrm{OH})_{2} \mathrm{D}_{3}$ and carboplatin each provided dose-dependent suppression of SKOV-3 growth, and

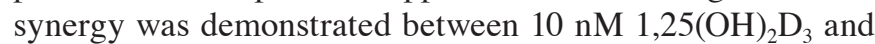
carboplatin. The proportion of cells in $\mathrm{G}_{0} / \mathrm{G}_{1}$ phase was markedly reduced by the drug combination, while the proportion of cells in $\mathrm{G}_{2} / \mathrm{M}$ phase was increased. Apoptosis did not increase

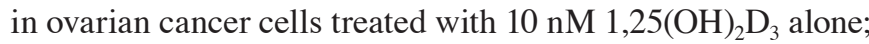
however, $1,25(\mathrm{OH})_{2} \mathrm{D}_{3}$ evidently enhanced carboplatin-induced apoptosis. Similarly, ROS production was evidently higher and MMP was lower in cells treated with the two drugs than in those treated with each drug alone. The results suggested that $1,25(\mathrm{OH})_{2} \mathrm{D}_{3}$ suppresses SKOV-3 growth and enhances the antiproliferative effect of carboplatin. The drugs function synergistically by inducing cell cycle arrest, increasing apoptosis and ROS production, and reducing MMP.
\end{abstract}

\section{Introduction}

Ovarian cancer is a serious global threat to female health and is a leading cause of cancer-related mortality in females,

Correspondence to: Dr Bingyan Li, Department of Toxicology, School of Public Health, Soochow University, 199 Ren'ai Road, Suzhou Industrial Park, Suzhou, Jiangsu 215123, P.R. China

E-mail: bingyanli@suda.edu.cn

*Contributed equally

Key words: 1,25-dihydroxyvitamin D3, carboplatin, ovarian cancer, SKOV-3 cells often due to late-stage recognition and aggressive tumor relapse (1). High patient morbidity is attributable in part to the recurrent growth of residual ovarian tumor cells that become resistant to standard chemotherapeutic treatments, and then aggressively proliferate and spread or metastasize to multiple sites. In total, $70 \%$ of females diagnosed with ovarian cancer present with advanced malignant disease and usually undergo surgery followed by a combination of paclitaxel and platinum-based chemotherapy $(2,3)$. However, recurrences occur in the majority of patients, and only $\sim 30 \%$ of patients with distant metastases survive five years following diagnosis $(4,5)$. Failure of chemotherapy in recurrent ovarian cancer is usually due to the development of resistance to one or the two main classes of chemotherapy agents used to treat ovarian cancer (6-8). Novel therapeutic approaches are therefore necessary for the management of advanced and recurrent ovarian cancer.

Platinating agents, such as carboplatin, are potent chemotherapeutic agents widely used for the adjuvant treatment of primary ovarian cancer and metastatic disease. The drug induces the formation of DNA adducts, $\mathrm{G}_{2}$ phase cell cycle arrest and the subsequent triggering of apoptosis. However, the efficacy of carboplatin is limited by drug resistance and side-effects, including nephrotoxicity, myelosuppression and neurotoxicity $(9,10)$. The mechanisms underlying the development of resistance to platinating agents, particularly carboplatin, include the repair of DNA lesions, translesion DNA synthesis, altered drug transport, increased antioxidant production and reduction of apoptosis (11-13). Altered gene expression affecting cellular transport, DNA repair, apoptosis and cell-cell adhesion are the mechanisms of platinum resistance that have been observed in patient samples $(14,15)$. Therapeutic success may therefore be improved if tumor cells can be sensitized to carboplatin treatment with a combination therapy.

$1 \alpha, 25$-Dihydroxyvitamin D3 $\left[1,25(\mathrm{OH})_{2} \mathrm{D}_{3}\right]$ is the most active metabolite of vitamin D3. It is a scarce natural product that is synthesized predominantly in the skin from 7-dehydrocholesterol by exposure to ultraviolet sunlight. Although its classical role as the major regulator of calcium homeostasis and bone formation/resorption has been recognized for some time (16), more recent findings suggest that $1,25(\mathrm{OH})_{2} \mathrm{D}_{3}$ is an important modulator of cellular proliferation and differentiation in a variety of benign and malignant cells. $1,25(\mathrm{OH})_{2} \mathrm{D}_{3}$ also exhibits anti-invasion, antiangiogenesis 
and antimetastatic activity in vivo (17-21) and acts as a chemopreventive agent in animal models of lung, colorectal and breast cancer (22-24).

The aim of this study was to determine whether $1,25(\mathrm{OH})_{2} \mathrm{D}_{3}$ enhances the cytostatic effects of carboplatin in SKOV-3 cells and to characterize the mechanism of its effect.

\section{Materials and methods}

Cell culture and agents. The human ovarian serous papillary cystadenocarcinoma SKOV-3 cell line was purchased from the Type Culture Collection of the Chinese Academy of Sciences (TCCCAS; Shanghai, China) and was verified as mycoplasma free. Authenticity of the cell line was confirmed by the TCCCAS. The SKOV-3 cells were maintained in RPMI 1640 medium supplemented with $10 \%$ fetal bovine serum, $100 \mathrm{U} / \mathrm{ml}$ penicillin and $5 \mathrm{mg} / \mathrm{ml}$ streptomycin. These agents and trypsin-EDTA solution were purchased from Invitrogen Life Technologies (Carlsbad, CA, USA). 1,25(OH $)_{2} \mathrm{D}_{3}$ and carboplatin were purchased from Sigma-Aldrich (St. Louis, MO, USA) and Qilu Pharmaceutical Co., Ltd. (Jinan, China), respectively. $1,25(\mathrm{OH})_{2} \mathrm{D}_{3}$ was dissolved in ethanol and stored in a concentrated solution $\left(10^{-5} \mathrm{~mol} / \mathrm{l}\right)$ at $-80^{\circ} \mathrm{C}$. The $1,25(\mathrm{OH})_{2} \mathrm{D}_{3}$ was freshly diluted in RPMI 1640 prior to each experiment. The ethanol concentrations in each experiment were $\leq 0.1 \%$. The carboplatin solution was prepared with sterile distilled water and fresh stocks were prepared on the day of each experiment, and dilutions were prepared with RPMI 1640.

Cell viability assay. The viability of SKOV-3 cells was determined by Cell Counting Kit-8 (CCK-8; Dojindo Laboratories, Kumamoto, Japan). Briefly, cells at the exponential phase were collected, transferred to 96 -well plates $(2,000$ cells/well) and cultured overnight. The plating medium was removed and replaced with a medium containing the appropriate concentration of vehicle $\left(0.1 \%\right.$ ethanol), $1,25(\mathrm{OH})_{2} \mathrm{D}_{3}(0.1,1$, $5,10,50,100,200$ and $500 \mathrm{nM})$ or carboplatin $(0.2,2,20$, 40, 80 and $160 \mathrm{mg} / \mathrm{l})$. The combined effects were evaluated by incubation with $1,25(\mathrm{OH})_{2} \mathrm{D}_{3}$ and carboplatin. Cells were allowed to grow for an additional $72 \mathrm{~h}$, then $10 \mu \mathrm{l}$ of CCK-8 solution was added and the cells were incubated for $1 \mathrm{~h}$. Absorbance (Abs) was measured at $450 \mathrm{~nm}$ in a microplate reader (BioTec Instruments, Inc., Winooski, VT, USA) and growth inhibition was calculated as the percentage difference of the treated cells versus the vehicle controls, according to the following formula: Inhibition rate $(\%)=[$ (Abs of vehicle control cells - Abs of treated cells)/Abs of vehicle control cells] x 100. Each experiment was performed in triplicate.

Data were analyzed using KaleidaGraph (Synergy Software, Reading, PA, USA) to determine the drug $\mathrm{IC}_{50}$ value. The combined index (CI) was used to evaluate the drug combination assays according to the following formula (25): $\mathrm{CI}=\mathrm{D}_{\mathrm{A}} / \mathrm{IC}_{50, \mathrm{~A}}+\mathrm{D}_{\mathrm{B}} / \mathrm{IC}_{50, \mathrm{~B}}$, where $\mathrm{D}_{\mathrm{A}}$ is the $\mathrm{IC}_{50}$ of drug $\mathrm{A}$ when $\mathrm{A}$ was combined with $\mathrm{B}, \mathrm{D}_{\mathrm{B}}$ is the $\mathrm{IC}_{50}$ of drug $\mathrm{B}$ when A was combined with $\mathrm{B}, \mathrm{IC}_{50, \mathrm{~A}}$ is the $\mathrm{IC}_{50}$ of $\operatorname{drug} \mathrm{A}$, and $\mathrm{IC}_{50, \mathrm{~B}}$ is the $\mathrm{IC}_{50}$ of drug $\mathrm{B}$. Each CI was calculated from the mean affected fraction at each drug ratio concentration in triplicate. $\mathrm{CI}>1, \mathrm{CI}=1$, and $\mathrm{CI}<1$ indicated antagonism, additive effect or synergy, respectively (26).
Cell cycle analysis. SKOV-3 cells were grown to $50 \%$ confluence in $35-\mathrm{mm}$ dishes and treated with the vehicle control, $10 \mathrm{nM} 1,25(\mathrm{OH})_{2} \mathrm{D}_{3}, 40 \mathrm{mg} / \mathrm{l}$ carboplatin, or a combination of the two drugs for $72 \mathrm{~h}$. The cells were harvested by pooling the floating cells with the trypsinized monolayers and were pelleted by centrifugation at $179 \mathrm{x} \mathrm{g}$ for $5 \mathrm{~min}$. Following fixation with cold $75 \%$ ethanol, the cells were resuspended in a solution of phosphate-buffered saline (PBS; $\mathrm{pH} 7.4$ ) containing $25 \mathrm{mg} / \mathrm{ml}$ propidium iodide (PI; Sigma-Aldrich), $0.1 \mathrm{mM}$ EDTA (Invitrogen Life Technologies) and $0.01 \mathrm{mg} / \mathrm{ml}$ DNase-free RNase (Invitrogen Molecular Probes, Inc., Eugene, OR, USA). The samples were incubated for $15 \mathrm{~min}$ at room temperature prior to cell cycle analysis using a FC500 flow cytometer (Beckman Coulter, Fullerton, CA, USA). Statistics were performed on 20,000 events per sample using MultiCycle DNA Content and DNA cell cycle analysis software (MutiCycle AV for Windows; Phoenix Flow System, Inc., San Diego, CA, USA).

Apoptosis assay. The number of apoptotic cells was determined using the Alexa Fluor 488 Annexin V/Dead Cell apoptosis kit (Invitrogen Life Technologies). Following treatment, the cells were harvested and washed with PBS, then suspended in PBS with PI and Annexin V. The cell suspensions were incubated in the dark for $15 \mathrm{~min}$ at $37^{\circ} \mathrm{C}$ and then analyzed on a FC500 flow cytometer.

Confocal laser-scanning microscopy was performed using an SP-2 confocal laser-scanning microscope (Leica, Wetzlar, Germany) equipped with an oil immersion objective (63X). Nuclear images were obtained at an excitation wavelength of $405 \mathrm{~nm}$ of 4',6-diamidino-2-phenylindole (DAPI).

Measurement of mitochondrial membrane potential $(M M P)$. MMP was measured using JC-1 dye (Invitrogen Life Technologies), a cationic dye that aggregates in the mitochondria of healthy cells; at high concentrations, JC-1 monomers (green fluorescence) form aggregates (red fluorescence). The ratio of the green/red fluorescence is independent of mitochondrial shape, density or size, and depends only on the membrane potential. MMP analysis was performed as previously described (27). Briefly, SKOV-3 cells were treated for $72 \mathrm{~h}$, then harvested and stained with $10 \mu \mathrm{M} \mathrm{JC}-1$ at $4^{\circ} \mathrm{C}$ for $1 \mathrm{~h}$ prior to flow cytometry analysis. JC-1 was excited with the 488-nm argon laser (Beckman Coulter) and JC-1 green and red fluorescence was recorded using $530 \mathrm{~nm} \pm 15 \mathrm{~nm}$ and a $590 \mathrm{~nm} \pm 15 \mathrm{~nm}$ band pass filter channels. A minimum of 20,000 cells within the gated region were analyzed. The cell sorting gates used were FL-2 versus FL-1 blotting (28). The ratio of the fluorescence intensity at $590 \mathrm{~nm}$ to that at $530 \mathrm{~nm}$ (FL-2:FL-1 ratios) was considered the relative MMP value. Data are presented as the mean of three experiments.

Measurement of intracellular reactive oxygen species (ROS). Intracellular ROS was measured by a cell-permeating probe, 5-[and-6]-chloromethyl-2',7'-dichlorodihydrofluorescein diacetate, acetyl ester (CM- $\mathrm{H}_{2}$ DCFDA, Invitrogen Molecular Probes), as previously described (29). CM- $\mathrm{H}_{2}$ DCFDA is a non-polar compound that is hydrolyzed upon cell entry, forming a non-fluorescent derivative that can be converted into a fluorescent product in the presence of a true oxidant. 
Mean fluorescence intensity was used as measure of ROS level as determined by flow cytometer. Cells were treated for $72 \mathrm{~h}$, washed and loaded with $10 \mu \mathrm{M} \mathrm{CM}-\mathrm{H}_{2}$ DCFDA for $1 \mathrm{~h}$. Green fluorescence intensity was used as a measure of relative intracellular ROS by flow cytometry at $530 \mathrm{~nm}$. A total of 20,000 cells within the gated region were analyzed. Data are presented as the mean of three experiments

Statistical analysis. Statistical analysis was performed using SPSS, version 13.0 for Windows (SPSS, Inc., Chicago, IL, USA). Data are presented as the mean \pm standard deviation. One-way analysis of variance was used to evaluate differences between the groups. $\mathrm{P}<0.05$ was considered to indicate a statistically significant difference.

\section{Results}

Dose-response of SKOV-3 cells to $1,25(\mathrm{OH})_{2} \mathrm{D}_{3}$ and carboplatin. Initial experiments were performed to determine the range of drug concentrations that would elicit growth inhibition in ovarian cancer cells. SKOV-3 cells were incubated with graded $1,25(\mathrm{OH})_{2} \mathrm{D}_{3}(0.1,1,5,10,50,100,200$ and $500 \mathrm{nM})$ and carboplatin $(0.2,2,20,40,80$, and $160 \mathrm{mg} / \mathrm{l})$. In the cell viability assay, $1,25(\mathrm{OH})_{2} \mathrm{D}_{3}$ inhibited growth in a dose-dependent manner (Fig. 1A). Carboplatin also suppressed the viability of SKOV-3 cells in a similar manner (Fig. 1B). The differences between the vehicle control and test groups were statistically significant $(\mathrm{P}<0.05)$. Based on $10-90 \%$ inhibition rates of cell growth in the KaleidaGraph program, the $\mathrm{IC}_{50}$ values of $1,25(\mathrm{OH})_{2} \mathrm{D}_{3}$ and carboplatin were $420.45 \mathrm{nM}$ $\left(\mathrm{R}^{2}=0.9904\right)$ and $54.6 \mathrm{mg} / \mathrm{l}\left(\mathrm{R}^{2}=0.9923\right)$, respectively.

Combined administration of $1,25(\mathrm{OH})_{2} \mathrm{D}_{3}$ and carboplatin. To determine whether the drugs work synergistically, SKOV-3 cells were treated with carboplatin in the presence of $1,25(\mathrm{OH})_{2} \mathrm{D}_{3}$. The growth inhibition was significantly greater with the combined treatment (Fig. 1C) and greater synergy was achieved at $40 \mathrm{mg} / \mathrm{l}$ carboplatin in combination with $10 \mathrm{nM} 1,25(\mathrm{OH})_{2} \mathrm{D}_{3}(\mathrm{CI}=0.57)$. The $\mathrm{IC}_{50}$ of carboplatin evidently decreased with increasing $1,25(\mathrm{OH})_{2} \mathrm{D}_{3}$ concentrations (Table I).

Cell cycle analysis. To determine whether $1,25(\mathrm{OH})_{2} \mathrm{D}_{3}$ enhancement of the antiproliferative activity of carboplatin was due to alterations in the cell cycle, the cell cycle distribution of SKOV-3 cells treated with the vehicle control, $10 \mathrm{nM} 1,25(\mathrm{OH})_{2} \mathrm{D}_{3}, 40 \mathrm{mg} / \mathrm{l}$ of carboplatin and the drugs in combination were compared. Compared with the vehicle control, $1,25(\mathrm{OH})_{2} \mathrm{D}_{3}$ significantly increased the percentage of cells in $\mathrm{G}_{0} / \mathrm{G}_{1}$ phase, accompanied by a reduction of cells in $\mathrm{G}_{2} / \mathrm{M}$ phase. The reverse effect occurred with carboplatin; a decrease in cells in $\mathrm{G}_{0} / \mathrm{G}_{1}$ phase and an increase in cells in $\mathrm{G}_{2} / \mathrm{M}$ phase was observed. However, the percentage of cells in $\mathrm{S}$ phase changed very little. Following treatment with $10 \mathrm{nM} 1,25(\mathrm{OH})_{2} \mathrm{D}_{3}$ and $40 \mathrm{mg} / \mathrm{l}$ carboplatin, the distribution of $\mathrm{G}_{0} / \mathrm{G}_{1}$-phase cells in SKOV-3 cells was further reduced, while cells in $\mathrm{G}_{2} / \mathrm{M}$ phase evidently increased (Fig. 2A and B). Therefore, it was concluded that the combined treatment had a similar effect as carboplatin treatment alone, but this observation regarding cell cycle arrest requires more consideration.
Table I. Effect of $1,25(\mathrm{OH})_{2} \mathrm{D}_{3}$ and carboplatin combination on the growth of SKOV-3 cells.

\begin{tabular}{ccc}
\hline $1,25(\mathrm{OH})_{2} \mathrm{D}_{3}, \mathrm{nM}$ & $\mathrm{IC}_{50}{ }^{\mathrm{a}}$ of carboplatin, $\mathrm{mg} / \mathrm{l}$ & $\mathrm{CI}^{\mathrm{b}}$ \\
\hline 0 & 54.6 & $\mathrm{NA}^{\mathrm{c}}$ \\
1 & 35.0 & 0.78 \\
10 & 26.7 & 0.57 \\
100 & 24.4 & 0.76 \\
\hline
\end{tabular}

${ }^{a} \mathrm{IC}_{50}$ (half the inhibitory concentration) of $1,25(\mathrm{OH})_{2} \mathrm{D}_{3}$ was $420.45 \mathrm{nM} .{ }^{\mathrm{b}} \mathrm{CI}>1$, antagonism; $\mathrm{CI}=1$, additive effect; and $\mathrm{CI}<1$, synergy. 'It was not possible to calculate the $\mathrm{CI}$ with a concentration of $0 \mathrm{~nm} 1,25(\mathrm{OH})_{2} \mathrm{D}_{3}$. CI, combined index; $1,25(\mathrm{OH})_{2} \mathrm{D}_{3}, 1,25$-dihydroxyvitamin $\mathrm{D}_{3}$.

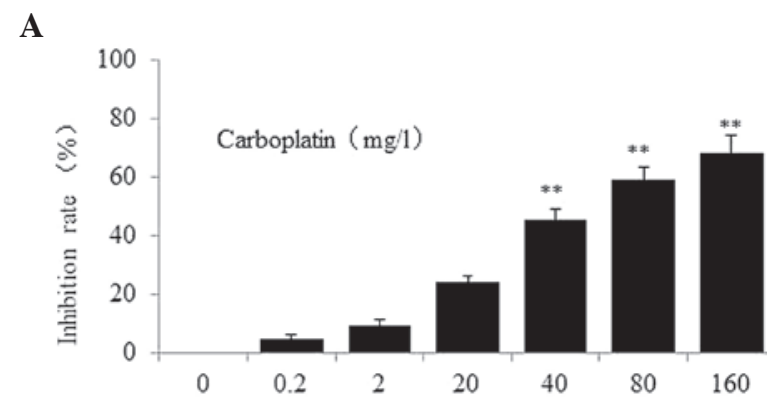

$\mathbf{B}$

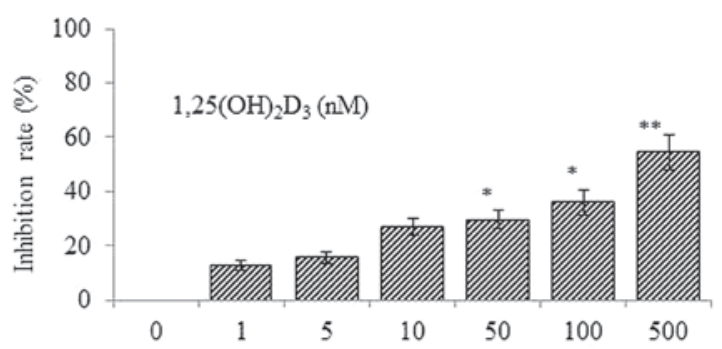

C

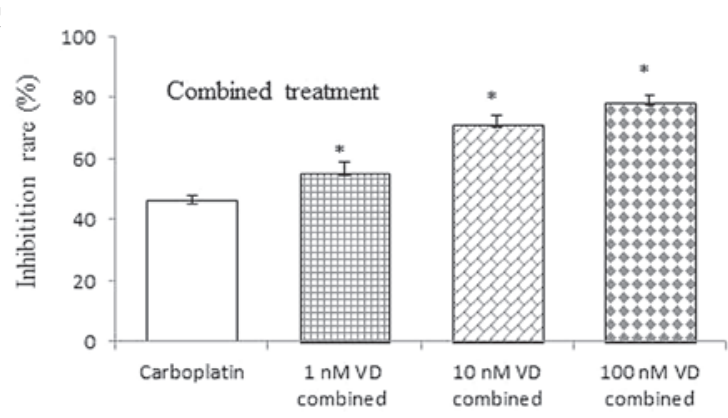

Figure 1. $1,25(\mathrm{OH})_{2} \mathrm{D}_{3}$ and/or carboplatin inhibition of SKOV-3 cell growth Growth inhibition increased with increasing doses of (A) carboplatin and (B) $1,25(\mathrm{OH})_{2} \mathrm{D}_{3}$ over $72 \mathrm{~h}$. ${ }^{*} \mathrm{P}<0.05$ and ${ }^{* *} \mathrm{P}<0.01$, vs. the vehicle control. (C) Growth inhibition also increased with combined $1,25(\mathrm{OH})_{2} \mathrm{D}_{3}$ and carboplatin treatment. ${ }^{*} \mathrm{P}<0.05$, vs. single-drug treatment. $1,25(\mathrm{OH})_{2} \mathrm{D}_{3}$, 1,25-dihydroxyvitamin $\mathrm{D}_{3}$.

Apoptosis in combination treatment of $1,25(\mathrm{OH})_{2} \mathrm{D}_{3}$ and carboplatin. Apoptosis was assessed to identify the mechanism of growth inhibition by the combined treatment of $1,25(\mathrm{OH})_{2} \mathrm{D}_{3}$ and carboplatin in ovarian cancer cells. Apoptosis was increased in SKOV-3 cells treated with $40 \mathrm{mg} / \mathrm{l}$ carboplatin, but the increase was not significant in 

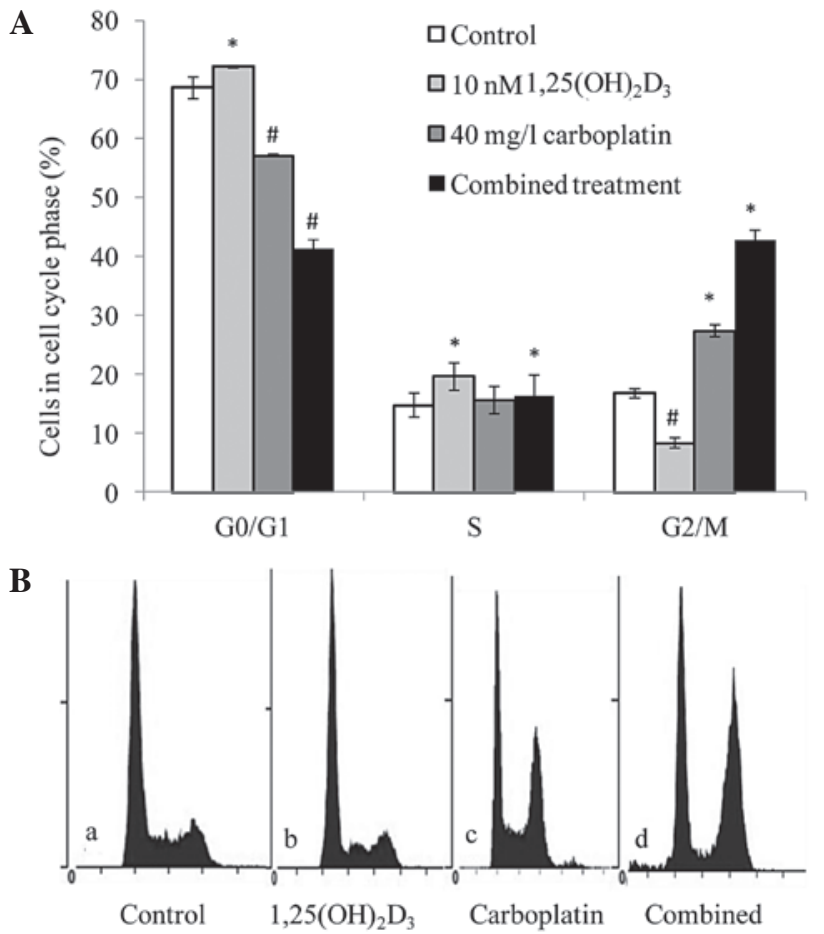

Figure 2. Combined effect of $1,25(\mathrm{OH})_{2} \mathrm{D}_{3}$ and carboplatin on cell cycle distribution. (A) $\mathrm{G}_{2} / \mathrm{M}$ cell cycle arrest in SKOV-3 cells treated with $1,25(\mathrm{OH})_{2} \mathrm{D}_{3}$ and carboplatin versus the untreated cells. ${ }^{* / /} \mathrm{P}<0.05$, vs. the vehicle controls. (B) Flow cytometric analysis: a, control group; b, 10-nM $1,25(\mathrm{OH})_{2} \mathrm{D}_{3}$ group; c, $40-\mathrm{mg} / \mathrm{l}$ carboplatin group; and d, combined treatment group. Similar results were obtained in all three experiments. $1,25(\mathrm{OH})_{2} \mathrm{D}_{3}, 1,25$-dihydroxyvitamin $\mathrm{D}_{3}$.

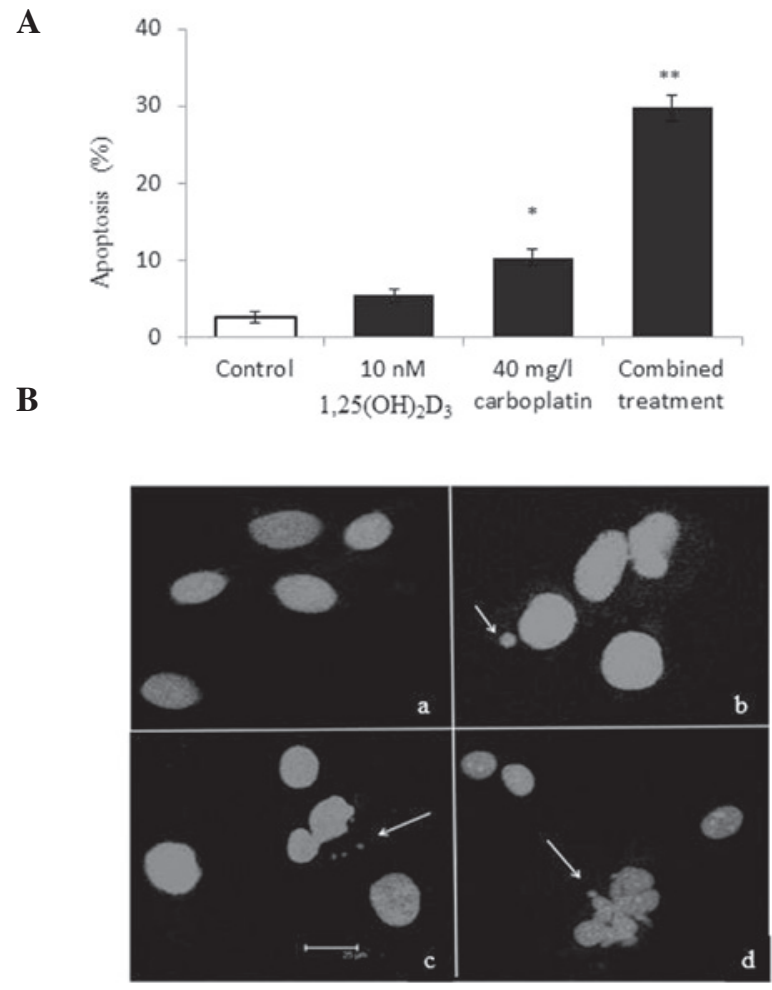

Figure 3.Combined effect of $1,25(\mathrm{OH})_{2} \mathrm{D}_{3}$ and carboplatin on apoptosis in SKOV-3 cells. (A) Apoptosis increased following the combined treatment of $1,25(\mathrm{OH})_{2} \mathrm{D}_{3}$ and carboplatin versus the untreated cells. ${ }^{*} \mathrm{P}<0.05$ and ${ }^{* *} \mathrm{P}<0.01$, vs. the vehicle controls. (B) Nuclei of SKOV-3 cells (stain, 4'6-diamidino-2-phenylindole): a, control group; b, 10-nM 1,25(OH) $)_{2} \mathrm{D}_{3}$ group; c, 40-mg/l carboplatin group; and $\mathrm{d}$, combined treatment group. Arrows indicate the fragmented DNA from the nuclei. $1,25(\mathrm{OH})_{2} \mathrm{D}_{3}, 1,25$-dihydroxyvitamin $\mathrm{D}_{3}$.
A

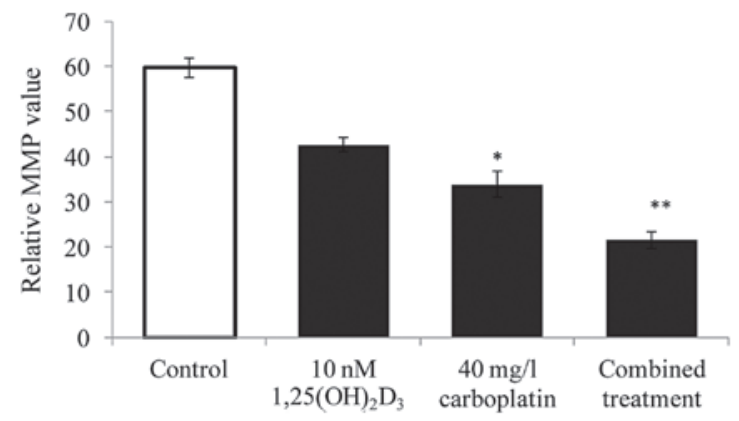

B

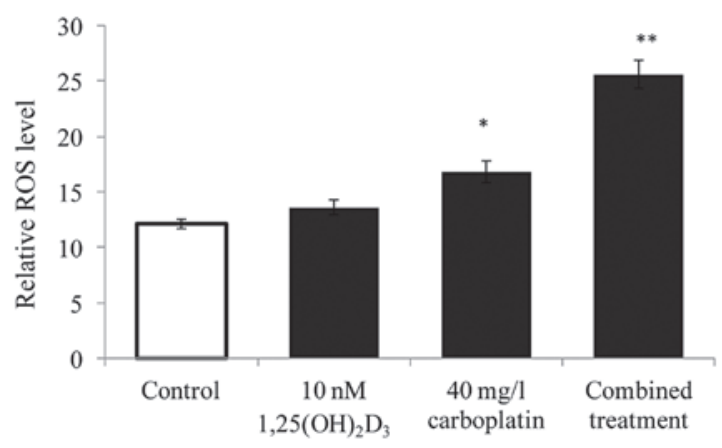

Figure 4. Combined effect of $1,25(\mathrm{OH})_{2} \mathrm{D}_{3}$ and carboplatin on ROS production and MMP loss in SKOV-3 cells. (A) MMP was reduced in SKOV-3 cells following combination treatment versus the controls. (B) ROS production increased in SKOV-3 cells following the combined treatment versus the untreated controls. ${ }^{*} \mathrm{P}<0.05$ and ${ }^{* * *} \mathrm{P}<0.01$, vs. the vehicle controls. 1,25(OH)2D3, 1,25-dihydroxyvitamin D3; ROS, reactive oxygen species; MMP, mitochondrial membrane potential.

cells treated with $10 \mathrm{nM} 1,25(\mathrm{OH})_{2} \mathrm{D}_{3}$ (a dose of $100 \mathrm{nM}$ did increase apoptosis, data not shown) compared with the control group. However, apoptosis was evidently increased by combined treatment (Fig. 3A). Furthermore, confocal laser-scanning microscopy with DAPI staining demonstrated that cells treated with the two drugs exhibited apoptotic nuclei with DNA fragmentation, chromatin condensation and formation of apoptotic bodies (Fig. 3B), and that cells treated with single drugs contained fewer apoptotic nuclei than cells treated with both drugs.

MMP change following combination treatment. Depolarization of MMP is a characteristic feature of apoptosis; hence, treated cells were examined for a drop in MMP. MMP was not found to significantly reduce with $10 \mathrm{nM}$ of $1,25(\mathrm{OH})_{2} \mathrm{D}_{3}$ in SKOV-3 cells, but MMP dropped in cells treated with $40 \mathrm{mg} / \mathrm{l}$ carboplatin. The maximal effect was obtained with combined $1,25(\mathrm{OH})_{2} \mathrm{D}_{3}$ and carboplatin treatment (Fig. 4A). Each drug alone inhibited growth, increased apoptosis and reduced MMP. Thus, $1,25(\mathrm{OH})_{2} \mathrm{D}_{3}$ further reduces the MMP of ovarian cells induced by carboplatin; however, $10 \mathrm{nM}$ of $1,25(\mathrm{OH})_{2} \mathrm{D}_{3}$ alone did not reduce MMP.

ROS production following combined treatment. Oxidative stress appears to be critical for tumor therapy, as ROS overproduction corresponds to an increase in apoptosis. In order to assess whether the growth suppression of $1,25(\mathrm{OH})_{2} \mathrm{D}_{3}$ and carboplatin is due to ROS production, ROS were measured as detected by $\mathrm{CM}-\mathrm{H}_{2}$ DCFDA and expressed as the mean fluorescence by flow cytometry in comparison with the vehicle 
controls. The ROS levels in cells treated with $40 \mathrm{mg} / \mathrm{l}$ carboplatin were evidently increased, while those of cells treated with $10 \mathrm{~nm} 1,25(\mathrm{OH})_{2} \mathrm{D}_{3}$ were not found to significantly increase in comparison with the vehicle control. Although carboplatin treatment alone increases ROS production, the combined treatment produced a clear increase in ROS levels compared with the vehicle control (Fig. 4B). Thus, the growth inhibition of ovarian cancer cells can be induced by the increase of ROS triggered by the combined treatment.

\section{Discussion}

The primary actions of $1,25(\mathrm{OH})_{2} \mathrm{D}_{3}$ are mediated through the nuclear vitamin $\mathrm{D}$ receptor (VDR), a member of the steroid/thyroid hormone superfamily of ligand-activated transcription factors. VDR has been found in rat ovaries by immunohistochemistry (30), as well as hen ovaries by ligand binding assays (31), indicating that the ovary is a target organ for vitamin D. Studies have also shown that VDR is expressed in gynecologic neoplasms, such as ovarian cancer $(32,33)$, which suggests that $1,25(\mathrm{OH})_{2} \mathrm{D}_{3}$ may be effective against ovarian cancer. The correlation between vitamin $\mathrm{D}$ and the risk of ovarian cancer has also received unprecedented attention. Several ecological studies have reported that ovarian cancer mortality inversely correlates with sun exposure, which initiates vitamin $\mathrm{D}$ production in the skin $(34,35)$. Other studies of dietary intake of vitamin $\mathrm{D}$ have also observed an inverse correlation with ovarian cancer risk $(36,37)$. Therefore, the inverse correlation between vitamin $\mathrm{D}$ level and ovarian cancer-related mortality suggests that the insufficiency of $1,25(\mathrm{OH})_{2} \mathrm{D}_{3}$ may contribute to ovarian cancer initiation and/or progression.

In this study, $1,25(\mathrm{OH})_{2} \mathrm{D}_{3}$ was demonstrated to inhibit ovarian cancer SKOV-3 cell growth in a dose-dependent manner. It also markedly enhanced the inhibitory effects of carboplatin on ovarian cancer cells at a concentration of $10 \mathrm{nM} 1,25(\mathrm{OH})_{2} \mathrm{D}_{3}$. While this has been viewed as the major anticancer effect for $1,25(\mathrm{OH})_{2} \mathrm{D}_{3}$, its mechanism remains uncertain.

Cell-cycle perturbation is central to chemotherapy-mediated antiproliferative activity in tumor cells, and combined treatment with $1,25(\mathrm{OH})_{2} \mathrm{D}_{3}$ and carboplatin in the current study led to a significant increase in the percentage of $\mathrm{G}_{2} / \mathrm{M}$-phase cells and an evident decrease in $\mathrm{G}_{0} / \mathrm{G}_{1}$-phase cells. Moffatt et al (38) also demonstrated that, over time, combined $1,25(\mathrm{OH})_{2} \mathrm{D}_{3}$ and carboplatin increases the percentage of prostate cancer cells in $\mathrm{G}_{2} / \mathrm{M}$ phase. The authors found this trend to correlate with an apparent decrease in the amount of cells in $\mathrm{G}_{1}$ phase. Studies of ovarian cells have suggested that $1,25(\mathrm{OH})_{2} \mathrm{D}_{3}$ causes cell cycle arrest at the $\mathrm{G}_{1} / \mathrm{S}$ and $\mathrm{G}_{2} / \mathrm{M}$ checkpoints. In addition, these studies have shown that the proliferation of ovarian cancer OVCAR3 cells is suppressed by $1,25(\mathrm{OH})_{2} \mathrm{D}_{3}$ (33) and that $1,25(\mathrm{OH})_{2} \mathrm{D}_{3}$ arrests ovarian cancer cells in $\mathrm{G}_{2} / \mathrm{M}$ phase by a mechanism that involves GADD45 (39). They have also indicated that $1,25(\mathrm{OH})_{2} \mathrm{D}_{3}$ arrests ovarian cancer cells in the $\mathrm{G}_{1}$ phase by increasing the abundance of $\mathrm{p} 27$, an inhibitor of cyclin-dependent kinase activity (40). 1,25(OH $)_{2} \mathrm{D}_{3}$ enhanced the effects of platinum agents by inhibiting the growth of the breast cancer cell line, MCF-7 (41). Additionally, in vivo evidence for the positive interaction between $1,25(\mathrm{OH})_{2} \mathrm{D}_{3}$ and platinum compounds has been obtained in a murine squamous cell carcinoma model system (42). These studies have shown that $1,25(\mathrm{OH})_{2} \mathrm{D}_{3}$ causes cell cycle arrest and growth suppression in ovarian cancer cells.

The results of the current study indicated that $1,25(\mathrm{OH})_{2} \mathrm{D}_{3}$ enhances the growth-inhibitory effect of carboplatin by increasing the rate of apoptosis. Furthermore, $1,25(\mathrm{OH})_{2} \mathrm{D}_{3}$ induced apoptosis, possibly due to increased ROS production, which directly induces single- and double-strand breaks, abasic sites and DNA fragmentation, all of which lead to apoptosis. Koren et al (43) reported that $1,25(\mathrm{OH})_{2} \mathrm{D}_{3}$ induces ROS production in MCF-7 cells and suggested a compensatory mechanism in which growth arrest is induced by oxidative stress, while antioxidant activities are increased. $1,25(\mathrm{OH})_{2} \mathrm{D}_{3}$ was not found to act synergistically with anticancer cytokines in the tumor milieu, which is mediated by ROS (44). In the present study, $10 \mathrm{nM} 1,25(\mathrm{OH})_{2} \mathrm{D}_{3}$ was not found to induce ROS production alone, but to enhance ROS production in ovarian cancer cells treated with carboplatin. These studies have demonstrated that the anticancer activity of $1,25(\mathrm{OH})_{2} \mathrm{D}_{3}$ is associated with the pro-oxidant action of $1,25(\mathrm{OH})_{2} \mathrm{D}_{3}$ its in MCF-7 cells, which may be the result of increased intracellular ROS. However, overproduction of ROS through endogenous or exogenous sources may induce DNA damage, the accumulation of which may lead to multistep carcinogenesis (45). Thus, the antioxidative effects of vitamin D have been suggested by epidemiological surveys and numerous in vitro and in vivo laboratory studies $(46,47)$. The antioxidative effect of vitamin D strengthens its roles in cancer chemoprevention and adds to a growing list of the beneficial effects of vitamin D in cancer (48).

One important observation from this study is that $1,25(\mathrm{OH})_{2} \mathrm{D}_{3}$ enhances the carboplatin-induced apoptosis of ovarian cells and is associated with the loss of MMP. Chen et al (49) also demonstrated that ergocalciferol, vitamin D2, causes HL-60 cell apoptosis via a drop in MMP. $1,25(\mathrm{OH})_{2} \mathrm{D}_{3}$ has also been found to augment the loss of MMP induced by TNF (50). Another finding has suggested that $1,25(\mathrm{OH})_{2} \mathrm{D}_{3}$ sensitizes breast cancer cells to ROS-induced death by influencing the caspase-dependent and -independent modes of cell death, upstream of mitochondrial damage (51). Therefore, $1,25(\mathrm{OH})_{2} \mathrm{D}_{3}$ enhances the anticancer effects of carboplatin through production of ROS and loss of MMP. Other studies have found that $1,25(\mathrm{OH})_{2} \mathrm{D}_{3}$ induces ovarian cancer cell apoptosis by downregulating telomerase, thus modulating telomere integrity or perhaps via a telomerase-independent mechanism (52). This result also indicates that $1,25(\mathrm{OH})_{2} \mathrm{D}_{3}$ may induce ovarian cancer cell apoptosis through various mechanisms.

In conclusion, the present study demonstrated that $1,25(\mathrm{OH})_{2} \mathrm{D}_{3}$ is a potent inhibitor of ovarian cancer cell growth in vitro, and enhances the therapeutic effects of carboplatin by altering the cell cycle and increasing apoptosis through changes in ROS and MMP. These findings suggest the potential utility of combining $1,25(\mathrm{OH})_{2} \mathrm{D}_{3}$ with cytotoxic agents for the treatment of ovarian cancer.

\section{Acknowledgements}

This study was supported by the National Natural Scientific Funding of China (grant nos. 81072286 and 81372979), and in part by the Priority Academic Program Development of Jiangsu Higher Education Institutions. 


\section{References}

1. Jemal A, Siegel R, Ward E, et al: Cancer statistics, 2007. CA Cancer J Clin 57: 43-66, 2007.

2. McGuire WP, Hoskins WJ, Brady MF, et al: Cyclophosphamide and cisplatin compared with paclitaxel and cisplatin in patients with stage III and stage IV ovarian cancer. N Engl J Med 334: 1-6, 1996.

3. Ozols RF, Bundy BN, Greer BE, et al; Gynecologic Oncology Group: Phase III trial of carboplatin and paclitaxel compared with cisplatin and paclitaxel in patients with optimally resected stage III ovarian cancer: a Gynecologic Oncology Group study. J Clin Oncol 21: 3194-3200, 2003.

4. Mutch DG: Gemcitabine combination chemotherapy of ovarian cancer. Gynecol Oncol 90: S16-S20, 2003.

5. Ozols RF: Systemic therapy for ovarian cancer: current status and new treatments. Semin Oncol 33 (Suppl 6): S3-S11, 2006.

6. Bookman MA, Brady MF, McGuire WP, et al: Evaluation of new platinum-based treatment regimens in advanced-stage ovarian cancer: a Phase III Trial of the Gynecologic Cancer Intergroup. J Clin Oncol 27: 1419-1425, 2009.

7. Stordal B, Pavlakis $\mathrm{N}$ and Davey R: A systematic review of platinum and taxane resistance from bench to clinic: an inverse relationship. Cancer Treat Rev 33: 688-703, 2007.

8. Markman M, Webster K, Zanotti K, et al: Survival following the documentation of platinum and taxane resistance in ovarian cancer: a single institution experience involving multiple phase 2 clinical trials. Gynecol Oncol 93: 699-701, 2004

9. Pavelka M, Lucas M and Russo N: On the hydrolysis mechanism of the second-generation anticancer drug carboplatin. Chemistry 13: 10108-10116, 2007.

10. Agarwal R and Kaye SB: Ovarian cancer: strategies for overcoming resistance to chemotherapy. Nat Rev Cancer 3: 502-516, 2003.

11. Cheng TC, Manorek G, Samimi G, et al: Identification of genes whose expression is associated with cisplatin resistance in human ovarian carcinoma cells. Cancer Chemother Pharmacol 58 : 384-395, 2006.

12. Rabik CA and Dolan ME: Molecular mechanisms of resistance and toxicity associated with platinating agents. Cancer Treat Rev 33: 9-23, 2007.

13. Roberts D, Schick J, Conway S, et al: Identification of genes associated with platinum drug sensitivity and resistance in human ovarian cancer cells. Br J Cancer 92: 1149-1158, 2005.

14. Peters D, Freund J and Ochs RL: Genome-wide transcriptional analysis of carboplatin response in chemosensitive and chemoresistant ovarian cancer cells. Mol Cancer Ther 4: 1605-1616, 2005.

15. Johnatty SE, Beesley J, Paul J, et al: ABCB1 (MDR 1) polymorphisms and progression-free survival among women with ovarian cancer following paclitaxel/carboplatin chemotherapy. Clin Cancer Res 14: 5594-5601, 2008.

16. Walters MR: Newly identified actions of the vitamin D endocrine system. Endocrinol Rev 13: 719-764, 1992.

17. Saunders DE, Christensen C, Williams JR, et al: Inhibition of breast and ovarian carcinoma cell growth by 1,25-dihydroxyvitamin D3 combined with retinoic acid or dexamethasone. Anticancer Drugs 6: 562-569, 1995.

18. Majewski S, Szmurlo A, Marczak M, et al: Inhibition of tumor cell-induced angiogenesis by retinoids, 1,25-dihydroxyvitamin D3 and their combination. Cancer Lett 75: 35-39, 1993.

19. Koli K and Keski-Oja J: 1alpha,25-dihydroxyvitamin D3 and its analogues down-regulate cell invasion-associated proteases in cultured malignant cells. Cell Growth Differ 11: 221-229, 2000.

20. Evans SR, Shchepotin EI, Young H, et al: 1,25-dihydroxyvitamin D3 synthetic analogs inhibit spontaneous metastases in a 1,2-dimethylhydrazine-induced colon carcinogenesis model. Int J Oncol 16: 1249-1254, 2000.

21. Peterlik M, Grant WB and Cross HS: Calcium, vitamin D and cancer. Anticancer Res 29: 3687-3698, 2009.

22. Akhter J, Chen X, Bowrey P, et al: Vitamin D3 analog, EB1089, inhibits growth of subcutaneous xenographs of the human colon cancer cell line, LoVo, in nude mouse model. Dis Colon Rectum 40: 317-321, 1997.

23. VanWeelden KV, Flanagan L, Binderup L, et al: Apoptotic regression of MCF-7 xenografts in nude mice treated with the vitamin D3 analog, EB1089. Endocrinology 139: 2102-2110, 1998

24. Mehta RG and Mehta RR. Vitamin D and cancer. J Nutr Biochem 13: 252-264, 2002.
25. Chou TC and Talalay P: Quantitative analysis of dose-effect relationships: the combined effects of multiple drugs or enzyme inhibitors. Adv Enzyme Regul 22: 27-55, 1984

26. Soriano AF, Helfrich B, Chan DC, et al: Synergistic effects of new chemopreventive agents and conventional cytotoxic agents against human lung cancer cell lines. Cancer Res 59: 6178-6184, 1999.

27. Smiley ST, Reers M, Mottola-Hartshorn C, et al: Intracellular heterogeneity in mitochondrial membrane potentials revealed by a J-aggregate-forming lipophilic cation JC-1. Proc Natl Acad Sci USA 88: 3671-3675, 1991.

28. Sung DK, Chang YS, Kang S, et al: Comparative evaluation of hypoxic-ischemic brain injury by flow cytometric analysis of mitochondrial membrane potential with JC-1 in neonatal rats. J Neurosci Methods 193: 232-238, 2010

29. Turturro F, Friday E and Welbourne T: Hyperglycemia regulates thioredoxin-ROS activity through induction of thioredoxin-interacting protein (TXNIP) in metastatic breast cancer-derived cells MDA-MB-231. BMC Cancer 7: 96, 2007.

30. Johnson JA, Grande JP, Windebank AJ and Kumar R: 1,25-Dihydroxyvitamin $\mathrm{D}(3)$ receptors in developing dorsal root ganglia of fetal rats. Brain Res Dev Brain Res 92: 120-124, 1996.

31. Dokoh S, Donaldson CA, Marion SL, et al: The ovary: a target organ for 1,25-dihydroxyvitamin D3. Endocrinology 112: 200-206, 1983

32. Ahonen MH, Zhuang YH, Aine R, et al: Androgen receptor and vitamin $\mathrm{D}$ receptor in human ovarian cancer: growth stimulation and inhibition by ligands. Int J Cancer 86: 40-46, 2000.

33. Saunders DE, Christensen C, Lawrence WD et al: Receptors for 1,25-dihydroxyvitamin D3 in gynecologic neoplasms. Gynecol Oncol 44: 131-136, 1992.

34. Garland CF, Garland FC, Gorham ED, et al: The role of vitamin D in cancer prevention. Am J Public Health 96: 252-261, 2006.

35. Grant WB: An estimate of premature cancer mortality in the U.S. due to inadequate doses of solar ultraviolet-B radiation. Cancer 94: 1867-1875, 2002

36. Bidoli E, La Vecchia C, Talamini R, et al: Micronutrients and ovarian cancer: a case-control study in Italy. Ann Oncol 12: 1589-1593, 2001.

37. Salazar-Martinez E,Lazcano-Ponce EC, Gonzalez Lira-Lira G, et al: Nutritional determinants of epithelial ovarian cancer risk: a case-control study in Mexico. Oncology 63: 151-157, 2002.

38. Moffatt KA, Johannes W and Miller GJ: 1Alpha,25dihydroxyvitamin D3 and platinum drugs act synergistically to inhibit the growth of prostate cancer cell lines. Clin Cancer Res 5: 695-703, 1999.

39. Jiang F, Li P, Fornace Jr AJ, et al: G2/M arrest by 1,25-dihydroxyvitamin D3 in ovarian cancer cells mediated through the induction of GADD45 via an exhonic enhancer. J Biol Chem 278: 48030-48040, 2003

40. Li P, Li C, Zhao X, et al: p27(Kip1) stabilization and G(1) arrest by 1,25 -dihydroxyvitamin $\mathrm{D}(3)$ in ovarian cancer cells mediated through down-regulation of cyclin E/cyclin-dependent kinase 2 and Skp1-Cullin-F-box protein/Skp2 ubiquitin ligase. J Biol Chem 279: 25260-25267, 2004.

41. Cho YL, Christensen C, Saunders DE, et al: Combined effects of 1,25-dihydroxyvitamin D3 and platinum drugs on the growth of MCF-7 cells. Cancer Res 51: 2848-2853, 1991.

42. Light BW, Yu W, McElwain MC, et al: Potentiation of cisplatin antitumor activity using a vitamin D analogue in a murine squamous cell carcinoma system. Cancer Res 57: 3759-3764, 1997

43. Koren R, Hadari-Naor I, Zuck E, et al: Vitamin D is a prooxidant in breast cancer cells. Cancer Res 61: 1439-1444, 2001.

44. Wiseman H: Vitamin D is a membrane antioxidant. Ability to inhibit iron-dependent lipid peroxidation in liposomes compared to cholesterol, ergosterol and tamoxifen and relevance to anticancer action. FEBS Lett 326: 285-288, 1993.

45. Poulsen HE, Prieme H and Loft S: Role of oxidative DNA damage in cancer initiation and promotion. Eur J Cancer Prev 7: 9-16, 1998.

46. Marchionatti AM, Picotto G, Narvaez CJ, et al: Antiproliferative action of menadione and $1,25(\mathrm{OH})_{2} \mathrm{D}_{3}$ on breast cancer cells. J Steroid Biochem Mol Biol 113: 227-232, 2009.

47. Koren R, Rocker D, Kotestiano O, et al: Synergistic anticancer activity of 1,25-dihydroxyvitamin $\mathrm{D}(3)$ and immune cytokines: the involvement of reactive oxygen species. J Steroid Biochem Mol Biol 73: 105-112, 2000

48. Bao BY, Ting HJ, Hsu JW and Lee YF: Protective role of 1 alpha, 25-dihydroxyvitamin D3 against oxidative stress in nonmalignant human prostate epithelial cells. Int J Cancer 122: 2699-2706, 2008. 
49. Chen WJ, Huang YT, Wu ML, et al: Induction of apoptosis by vitamin D2, ergocalciferol, via reactive oxygen species generation, glutathione depletion, and caspase activation in human leukemia cells. J Agric Food Chem 56: 2996-3005, 2008.

50. Weitsman GE, Ravid A, Liberman UA and Koren R: Vitamin D enhances caspase-dependent and independent TNF-induced breast cancer cell death: the role of reactive oxygen species. Ann N Y Acad Sci 1010: 437-440, 2003.
51. Weitsman GE, Koren R, Zuck E, et al: Vitamin D sensitizes breast cancer cells to the action of $\mathrm{H} 2 \mathrm{O} 2$ : mitochondria as a convergence point in the death pathway. Free Radic Biol Med 39: 266-278, 2005.

52. Jiang F, Bao J, Li P, et al: Induction of ovarian cancer cell apoptosis by 1,25-Dihydroxyvitamin D3 through the down-regulation of telomerase. J Biol Chem 279: 53213-53221, 2004. 